\title{
Monsoons and Paleomonsoons
}

\author{
by Rhodes W. Fairbridge
}

This article presents a geological view of a central problem in climatology. Statistically the monsoon is well documented, but how does it work? Studies of paleoclimates may help to provide useful data, for example through the activities of the INQUA, the International Union for Quaternary Research.

\section{Introduction}

The 20th century has seen fundamental revolutions in the central sciences dealing with the Quaternary. In biology we have seen the discovery of the genetic code and the general acceptance of punctuated evolution, and in geology we have evolved from a fixistic to a dynamic Earth with continental drift, sea-floor spreading and plate tectonics. In climatology some specialists believe that we will shortly achieve the "break-through" recognition of exogenetic control of climate change through planetary orbital modulation and solar radiation. Each of the three reflects a giant intellectual leap forward in our philosophical outlook on seience. Each reflects a change from a rather static approach to science, shifting from the observational, cataloguing and classification phase to new paradigms characterized by dynamic hypotheses.

A major role in this intellectual change of approach has been played by the computer, which has liberated scientists from the chains of simple data-gathering and opened up exciting vistas of process dynamics. This is not to "put down" the explorer, the pick and hammer geologist, the palynologist with the auger, or the dendrochronologist with coring tool. The observational data are still vital - indeed, more are desperately needed. But what the new models are bringing forward is an endless crop of new ideas that need to be checked out in the field and new concepts of where to look for critical evidence.

The guiding philosophy in the study of the Quaternary is the long-established Principle of Actualism. This is the assumption that we interpret processes inferred for the

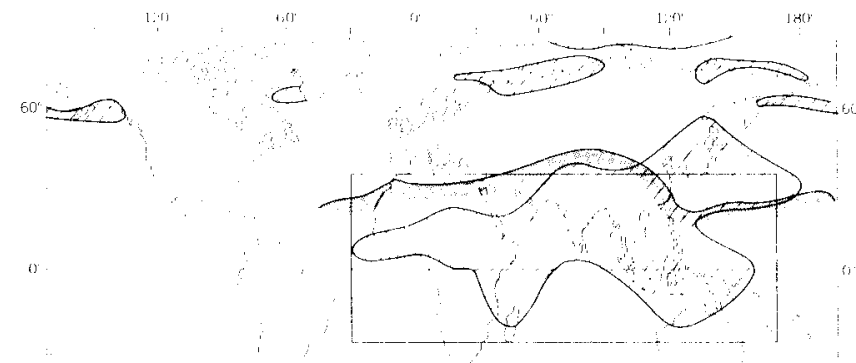

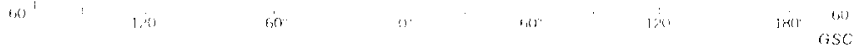

Figure 1: Global distribution of monsoonal regions. Heavy line with stippled edge indicates the northern limit of typical conditions. After Ramage (1971). geological past in terms of the physical laws and principles operating today, it being understood that there have bent appreciable variations in the duration and intensity of the various factors. This principle is subtly distinctive from the broader Principle of Uniformitarianism, which quite rightiy claimed that "the present is the key to the past." llowev., the followers of Sir Charles Lyell and many 19 th centwy authorities tended to overstate the uniformitarianist pr:t:ciple in terms of assuming an unchanging global cnviro:ment. According to Loomis (1868), for example, "the climate of a country remains permanently the same from age to age."

\section{Monsoons: A Human Problem}

The selection of the subject "Wonsoons and Paleomonsoom" for discussion during the 1987 INQUA Congress reflects tie importance perceived by nodern climatic scientists in the interdisciplinary values inherent in the INQUA composition a mixture of geologists, botanists, archeologists, envirchmentalists, climatologists and geophysicists, all dedicated to the study of the last 2 million years of the planet Eart is's history, and its physical and biological systems.

Monsoons are immensely important to mankind. The two largest countries in the world in terms of human population - India and China - both depend on the monsoonal rains for their agricultural livelihood. The intensity of those rains is notoriously variable, and when they fail, particularly in the semi-arid lands near the outer limits of the monsoonal air flows in North and East Africa, northern Australia and elsewhere, the resultant droughts are liable to be catastrophic. Unexpected floods can be likewise disastrous. The 1982 monsoon killed 1818 people in India, flooding 85 million acres and causing $\$ 1.7$ billion in damage. In the 1983 monsoon the death toll was 982 .

\section{What is a Monsoon?}

The general characteristics of the modern monsoon are in the textbooks (Pédelaborde, 1963; Das, 1968; Reihl, 1979; Ramage, 1971; Hastenrath, 1985). The term monsoon (in French, mousson) comes from the Arabic word mausin, which means "season." It is the regime of summer season wind and precipitation in the subtropies of either hemisphere that replaces the usual $\mathrm{NE}$ or $\mathrm{SE}$ trade wind with a transequatorial $\mathrm{SW}$ or $\mathrm{NW}$ airflow, following the seasonnl shift of the Intertropical Convergence Zone (ITCZ).

Figure 1 shows the climate regions where the seasonal wind reversal exceeds $120^{\circ}$. Only those areas within the rotangle enclosing southern Asia, Africa and northern A ustralia are normally classified as "monsoonal." Several monsoon-type climatic systems are recognized around the world (see, for example: Gentilli, p. 613 in Fairbridge, 196?; Pédelaborde, 1963; Riehl, 1979), but the focus here is mainily on the Asiatic phenomenon.

The classical Asiatic monsoon was observed by Alexander in his campaign to the mouth of the Indus and the Arabian soa ( 325 B.C.) and was described in detail by Aristotle in tiis "Meteorology." The commonly accepted explanation was presented in a paper to the Royal Society in London by sir Edmund Halley (1686). During the northern winter season, 
there is cooling with snow over Central Asia, developing a quasi-stable high pressure system that leads to a radial out-flow of cold, dry air towards the Indian Ocean and the western Pacific (Fig. 2).

1)uring the summer season the system reverses, and Central Asia is warm, developing quasi-stable low-pressure cells. As a result, humid maritime air flows in from the Indian Ocean and western Pacific (Fig. 3). Heavy "monsoonal" rains fall in India, southeast Asia and southern China. Locally they are orographically amplified, so that, for example, in parts of Assam, in the three "monsoon nonths" of June, July and August, precipitation averages more than $1,200 \mathrm{~cm}$. The annual record for (horrapungi $(1860 / 61)$ was $2647 \mathrm{~cm}$. The average annual discharge of the Brahmaputra River is $20,000 \mathrm{~m}^{3} \mathrm{sec}\left(620 \mathrm{~km}^{3} / \mathrm{yr}\right)$; the Changjian (Yangtze) and the Ganges (before damming) are similar.

During the northern winter, the flow of air outward from Asia crosses Indonesia and the equator to reach northern Australia as a summer "Northwest Nlonsoon," pieking up moisture and ereating in that semi-arid land a small-scale summer monsoon known simply as "The wet" (from December to February). At irregular intervals, as discussed later, this monsoonal flow joins an equatorial westerly flow as part of the complex fluctuations of the "Walker Cireulation," the El Niño-Southern Oscillation (ENSO), and the Quasibiemial Oscillation (QBO). Sudden warming of the central pacific sea-surface temperature (SST) causes atmospheric pressure to fall and mean sea level (IVISL) to rise both barometricaliy and sterically (i.e. by thermal expansion). The warm air rises and the lower stratospheric wind blows from cast to west (the "krakatoa Easterlies," first observed in 1883). An anomalously cool high-pressure cell develops over the Indian Ocean and then sinks, leading to a weak Indian Monsoon. Mean sea level rises in Darwin and Jakarta (DeBoer, in Fairbridge, 1967, p. 570).

Table I illustrates the record of two centuries (1781-1985) 10 show the see-saw behaviour of the Southern Oseillation. sot indicates high pressure over the pareific and low over the Indian Occan, while so- indicates the reverse. A major $\mathrm{SO}-$ situation is marked by an $\mathrm{LI} \mathrm{N}$ iño, and most, though not all, such events are associated with weak or late monsoons in India. Weak monsoons in West Africa of ten match the so+.

Quite clearly, if we could figure out the mechanism and catuses of these atmospheric oscillations, which are now increasingly recognized as global (Philander, 1983; Rasmussen and Wallace, 1983), we would be a long way ahead on the road to predicting tropical climate patterns a

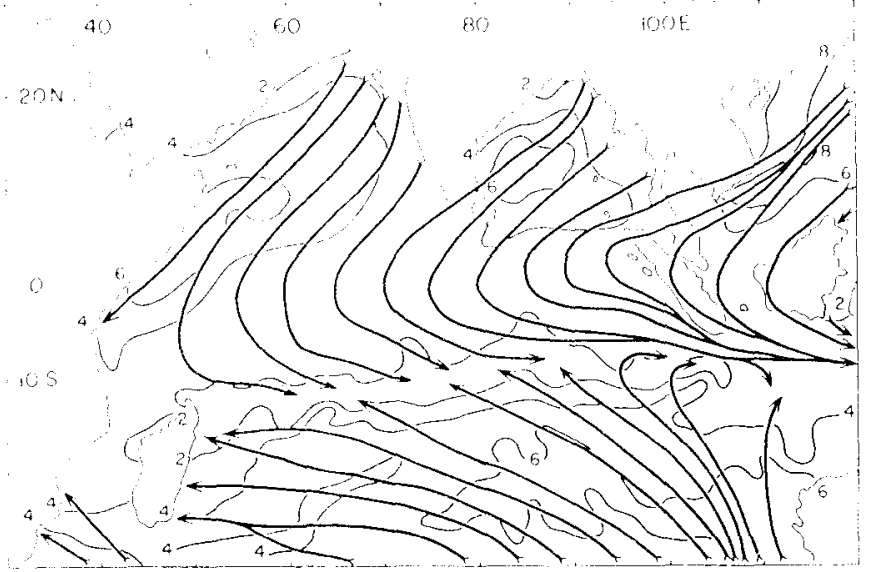

Fiqure 2: Streamines of airflow over the Indian ocean in January. Contours (light lines) indicate areas of equal wind velocity (ms-1). After Iastenrath and Lamb (1980). few years in advance. Such prediction could revolutionize the agricultural economies and relieve untold human suffering. Although some solar and also lunar periodicities are clearly detectable, the times of excessive rainfall appear at first sight to be randomly distributed (Mooley and Parthasarathy, 1984). But perhaps a new approach might help.

This is where the interdisciplinary scientists brought together by INQUA come in - micropaleontologists, palynologists, paleoclimatic modellers and others. 'The trouble is that the arcane language of these varied specialists is as incomprehensible to many geologists as it is to most of meteorologists. Let us try to forge some intellectual links, by reviewing some recent discoveries of paleoclimatology.

\section{Orbital Forcing}

Variations of effective solar radiation ("insolation" controlled by orbital changes as specified by the Nilankovitch Theory) are now accepted as the fundamental basis for exogenetic control of climate changes on the time seale of 10,000 to $1,000,000$ years. On this scale, there is no yearto-year climatic signal, but a nutation (wobble) in the 20,000-ycar precession cycle is caused by the Moon's 18.6year nodal cycle. 'There are also other small variations from year to year in the orbits of the Earth, Woon, Sun and planets (Borisenkov et al., 1983), not only in orbital radii, but also angular velocities and spin rates, that must affect our climate. Certain celestial events seem to be approximately synchronous, with at least some suggestive links, with terrestrial climatic extremes.

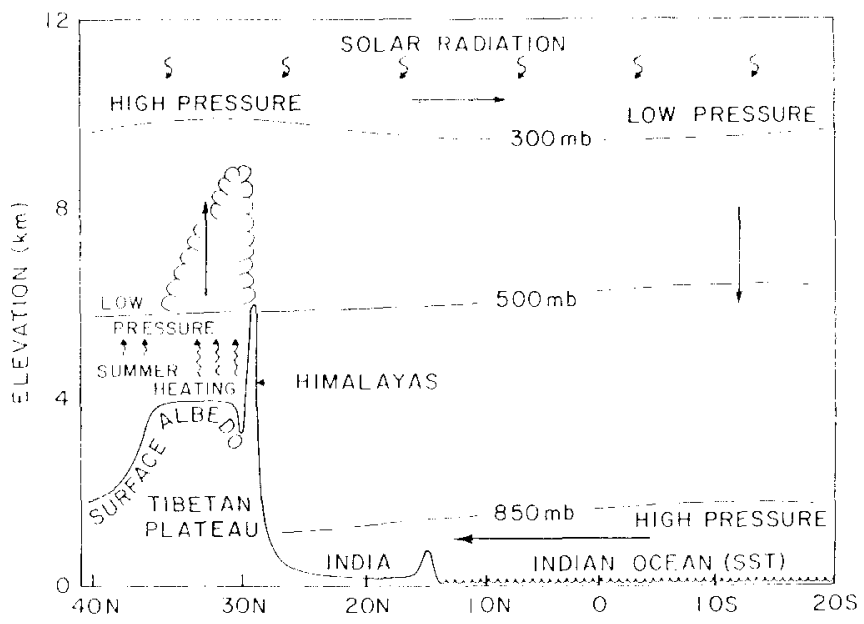

Figure 3: The flow of sumner monsoonal air towards low pressure zones developed by solar heating over Central Asia. See text for explanation. Simplified after Prell (1984).

In 1974-75, the Sun passed its peribac (the closest approach to the center of mass in the Solar System), undergoing an abrupt acceleration in orbital velocity (a "solar jerk"), accompanied by showers of very high-energy flares (over 10 ${ }^{10} \mathrm{erg} \mathrm{sec}^{-1} \mathrm{~cm}^{-2}$ ), affecting the geomagnetic field and high-latitude atmospheric circulation (see later section on Solar Bursts). The fiarth's spin rate and orbital velocity both underwent a dramatic acceleration, and the atmospheric angular momentum responded with an abrupt rise. Canada suffered one of the coldest winters on record, and India one of the ten wettest monsoons in 100 years. There seems, thus, to be a relationship between Earth's motion (both orbital and spin) and the alternation between zonal and blocking climate cycles. 


\section{Climatic Continentality Index}

At the beginning of the Holocene, 10,000 years ago, the general physical geography of the Earth was little different from that of today, sea-floor spreading and mountainbuilding having growth rates of less than a few $\mathrm{cm} / \mathrm{yr}$. Sea-level was then about $35 \mathrm{~m}$ lower than today, which would mean a somewhat decreased continental-shelf width and an increase in the climatic effect of a larger continental area (i.e. an elevated "continentality index"). But one key element was quite different: the Earth's spin-axis orientation (the 220,000 -year precession parameter).

The Earth at that time was tilted in space so that during mid-summer in the northern hemisphere it was also closest to the Sun, and this area received the highest possible radiation. Summers tended to be very warm and winters very cool. 'I'hat situation is now reversed, and the southern hemisphere enjoys that condition. The latter, however, is a dominantly oceanic realm because of the present plate-tectonic asymmetry, which specifies that the northern hemisphere has a high continentality index: this in turn tends to amplify all climatic variables. We must therefore look to the world's largest northern land mass, Eurasia, for clues as to the monsoonal variance (see later section on Ocean Temperatures), as well as to the effects of solar emissions discussed earlier.

\section{The "Solar Constant"}

For a century or more, there have been arguments about the possible variation of the "solar constant." Geologists have pointed not only to the 3.8 Ga year continuity of the paleontological record and sedimentological proof of essentially stable global climate $\left(15 \pm 3^{\circ} \mathrm{C}\right)$, but also to the incontrovertible evidence of periodic fluctuations that cannot be explained entirely by tectonism, volcanisin or other endogenetic causes. For long-term variability an external determinism is now widely accepted (Kampino and Stothers, 1984). Galactic and solar systemic motions are

\section{TABLE}

Southern Oscillation and El Niño for 200 Years

\begin{tabular}{|c|c|c|c|c|c|c|c|}
\hline $\mathrm{SO}^{+}$ & SO- & EN & $1 \mathrm{Wl}$ & $\mathrm{SO}+$ & so- & $\mathrm{EN}$ & Iivi \\
\hline $1781 \mathrm{~d}$ & 1783 & & & $1882 \mathrm{~d}$ & $1884 / 5$ & $x x$ & \\
\hline $1789 \mathrm{~d}$ & $1791 / 92$ & $x x$ & & 1886 & $1887 / 88 / 89$ & $x$ & $w$ \\
\hline 1797 & 1799 & & & 1890 & 1891 & $x x$ & $w$ \\
\hline $1800 / 01$ & $18193 / 04$ & $x x$ & & $1892 / 93$ & 1896 & $x$ & $w$ \\
\hline $1805 / 06$ & $1807 / 08$ & & & 1898 & $1899 / 1900$ & $x x$ & $W$ \\
\hline 1810 & 1814 & $x x$ & & $(1901)$ & 1902 & $\mathrm{X}$ & \\
\hline 1815 & $1816 / 17$ & $x$ & & $(1904)$ & 1905 & $\mathrm{x}$ & \\
\hline 1818 & 1819 & $x$ & & 1910 & $1911 / 12$ & $x X$ & $w$ \\
\hline$(1820) \mathrm{d}$ & 1821 & $\mathrm{x}$ & & $1913 \mathrm{~d}$ & 1914 & $\mathrm{x}$ & \\
\hline 1823 & 1824 & $\mathrm{x}$ & w & 1916 & $1917 / 18 / 19$ & $\mathrm{x}$ & w \\
\hline 1825 & $(1826)$ & & & 1921 & 1923 & $x$ & \\
\hline 1827 & $1828 / 29$ & $x x$ & $W$ & 1924 & $1925 / 26$ & $x x$ & \\
\hline 1831 & $18: 32$ & $x$ & $W$ & 1927 & $1929 / 30$ & $x$ & $w$ \\
\hline 1833 & $1835 / 36 / 37$ & $x$ & $w$ & 1931 & 1932 & $\mathrm{x}$ & $w$ \\
\hline 18411 & 1841 & & & 1934 & $(1.936)$ & & $w$ \\
\hline 1843 & $1844 / 45 / 46$ & $X X$ & $n$ & 1938 & $1939 / 40 / 41$ & $x X$ & W \\
\hline 1847 & $(1848)$ & & $W$ & $(1942)$ & $1943 / 44$ & $\mathrm{x}$ & $w$ \\
\hline 1849 & 1850 & $x$ & $w$ & $1945 \mathrm{~d}$ & 1946 & $(X)$ & W \\
\hline $1851 \quad \mathrm{~d}$ & 1852 & $x$ & & 1947 & 1948 & $(x)$ & $W$ \\
\hline$(1853)$ & $1854 / 55$ & $x$ & $w$ & 1950 & 1951 & $\mathrm{X}$ & $W$ \\
\hline 1856 & 1857 & $x$ & $w$ & 1952 & 1953 & $x$ & $W$ \\
\hline$(1859)$ & $(1860)$ & & $w$ & $1955 / 56$ & $1957 / 58$ & $x x$ & $w$ \\
\hline $1862 / 63$ & 1964 & $X X$ & $w$ & $1961 / 62$ & 1963 & $(\mathrm{X})$ & \\
\hline 1865 & 1866 & $x$ & & 1964 & 1965 & $\mathrm{X}$ & $w$ \\
\hline (1867) & 1868 & $(X)$ & & $1967 / 68$ & $1969 / 70$ & $x$ & \\
\hline 1870 & 1871 & $x x$ & & 1971 & $1972 / 73$ & $x x$ & \\
\hline 1872 & 1873 & $(X)$ & $W$ & $1971 / 750$ & 1976 & $x$ & \\
\hline 1975 & $1877 / 78$ & $x \lambda$ & & $(1978)$ & $(1980)$ & & \\
\hline 1879 & 1880 & $\mathrm{x}$ & & $\begin{array}{l}1981 \\
1985\end{array}$ & $1982 / 83$ & $x \times x$ & \\
\hline
\end{tabular}

Parentheses = matyinal cases. LN - LI $\mathrm{N}$ iño $(\mathrm{X}=$ moderate; $\mathrm{X} X=$ great $\mathrm{XXX}=$ exceptional). I $W$ - Indian iblonsoon ( $W=$ weak). $\mathrm{d}=31$-year Sahel drought eycle. i) ta from sehove, 1983 , and others. astronomically known, within reasonably rigid constraints, to be involved in complex, eyclic and predictable varit tions. Recent analyses demonstrate periodicities an related forcing functions that seem to correlate with climatic variables on a time frame of 1 to 1,000 vears (Fairbridge, 1982).

There has unfortunately been a general refusal by manv meteorologists to accept or even consider those variatiois as a part of our modern global environmental cosmos, on the grounds that the linkage mechanisms are not yet furnished with cast-iron proof (Pittock, 1983). Clearly, we have a long way to go. Satellite monitoring has now proved, how ever, that there is currently a secular decline in sol:1 radiation, which is due incidentally to swing upwards again about $\mathrm{AD}$ 1990. 'This is probably part of the 22 -year cycle $\mathrm{m}$ the reversal of the solar magnetic field. It deserves clost watching, but at least the vexed question of solar irradiance? variability is now, in principle, demonstrated. This gives us at least two eategories of exogenetic variables: orbitid changes and energy emission changes; but there are mol'e (see below).

\section{Monsoons and Solar Cycles}

Since early in the present century, attempts have been marie to correlate monsoonal variance to the 11 - and 22-year solix cycles, but serious difficulties have bedevilled predictive efforts. "These two "cycles" of solar activity have, unfortunately, such a large degree of variance (e.g., $11 \pm 6$ years between the sunspot maxima peaks, according to Schove (1983), that prediction has become a nearly suicidaliy hazardous sport. Furthermore the amplitudes of the cycles are extremely variable and are associated with important atmospheric feedbacks, positive and negative.

During the last few years, a number of helpful developments have occurred. First, the limitations of the short period of solar observations have been partly overcome by the use ot historical proxies, largely unearthed from ancient Chinese archival material on auroras, which had value for astrology and fortune-telling. For example a fiery dragon fancifuliy seen in an aurora can be calibrated with its modern equivalent and this given a quantitative value of probable sunspot equivalence. Phase, length and amplitudes of solur cycles can now be correlated with astronomically predictable planetary periods (Jose, 1965; Fairbridge, 1984; Landscheidt, 1984). With these data in hand, one can now potentially relate specific monsoonal climate patterns with planetary-solar events, even if we do not know the linkage mechanisms.

\section{Solar Bursts}

Modern solar observations show that, in addition to the 11 or 22-year cycles, there are times with additional displays of solar emission energy that alternate with extended periods of weak activity without "sudden commencement storms" (Legrand and Simon, 1985). High-energy white-light flares occur in clusters every few years, releasing more than $10^{10} \mathrm{erg} \mathrm{sec}^{-1} \mathrm{~cm}^{-2}$. Charged particle showers near the Earth's North ivagnetic Pole trigger extraordinarily low pressure fields that disturb global circulation (Bucha, 1984). It seems that the very high-energy flares are generally associated with the changes in torque (the "solar jerk") applied by planetary stress (Landscheidt, 1984). Thus, yet another exogenetic climate-disturbing source is becoming more predictable.

\section{Tidal Influences}

Still another disturbing force is the lunar and luni-solar tidil potential. Tides affect atmosphere, ocean and lithosphero. Until recently, claims of their effect on the weather were regarded as "old wives tales," but a large number of longterm weather and tree-ring records show conclusively the presence of the 18.6-year lunar nodal cycle (Currie, 1984; Currie and Fairbridge, 1985). Many other time series now 

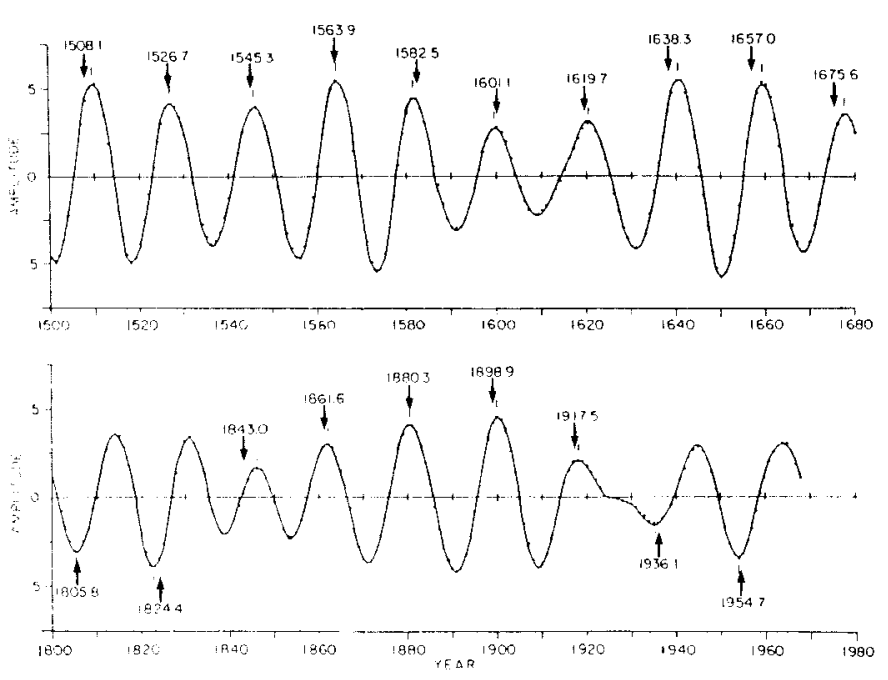

Figure 4: Two segments of the drought/flood record from Beijing and vicinity in northern China. See text for explanation. After Currie and Fairbridge (1985).

disclose the same periodicity, including tide gauge records, shelf-water temperatures, volcanic eruptions and major earthquakes.

Temperature and monsoonal precipitation series from both India and China suggest the same influence, as illustrated in Figure 4. This shows in wave form periods of dryness (positive polarity - up) and floods (negative polarity down). The arrows indicate epochs of the 18.6-year lunar nodal tide (near maximum declination). Note the curious changes of phase in the 1800s and the 1930-1960 period ("bistable phasing") both correspond to episodes of unusually low solar activity (fewer than 80 average spots at maxima).

Lunar signals tend to increase when sunspot numbers are low, and also when the subtropical high is weak (Lawrence, 1965). One may ask, nevertheless, if the speatral analyses show so many peaks, how do we discriminate which of the various modulations is going to dominate the next decade? Recent studies by Guiot (personal communication, 1984) have shown that in the Canadian Aretic, the solar and lunar impulses may at times reinforce one another, whereas at others they may cancel each other. Figure 5, for example, shows a positive correlation between the East Asian monsoon (expressed as 5-year means of summer rainfall at Hong Kong) and the 5-year mean annual sunspot numbers. This figure should be subtitled "a witeh's warning," for Bell

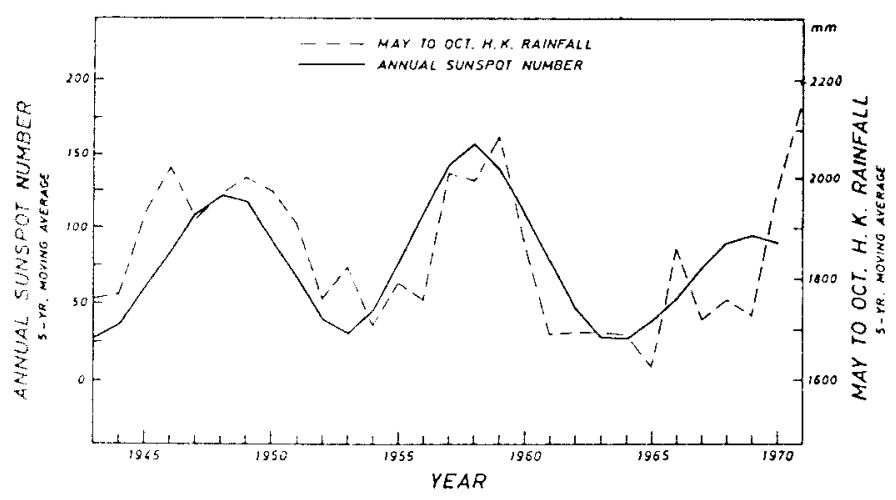

Figure 5: Correlation between annual sunspot numbers and summex rainfall at Hong Kong. After Bel1 (1977).
(1977) points out that an earlier time series (1900-1939) showed negative correlation between the same parameters. In this earlier series, the sunspot minima are close to the lunar tide maxima, with 1913 identical to the 18.6-year nodal cycle, and 1912 was the perigee-syzygy-declination maximum. In the later series, on the other hand, the nodal declination tide is close to the sunspot maxima; $1947-48$ was a lunar perigee-syzygy peak.

Figure 6 gives another example, this one from India. Note the wide scatter of correlation coefficients here, with positive and negative sunspot correlations around 1910 , in contrast to the close correspondence in the late $1940 \mathrm{~s}$. Phase reversal is still a major problem (Bell, 1977; Bell, 1981; Currie, 1984). The widely observed switch, around 1920-25 (Fig. 6), was marked by a change from zonal to meridional circulations in the mid-latitudes and may reflect the reversal of solar polarity (the 22-year "Hale Cycle").

\section{Geomagnetic Inputs}

A fascinating and complex area of study concerns the Earth's magnetic field and its interactions with the magnetic component of the solar wind. The lacustrine sediment-core studies of Creer (1981), Banerjee et al. (1979), Thouveny et al. (1985) and others disclose that over the last 20,000 years and more there has been a secular fluctuation of the geomagnetic field intensity, declination and inclination, with periods of the order of 500 to 2,500 years. Storm cycles recorded in the 8,000-year raised beach sequences of northern Canada disclose a 45-year cycle with an analogous and probably synchronous modulation

(Fairbridge and Hillaire-Marcel, 1977), and these in turn tie in with the climatic palynology of Quebec (Filion, 1983) and the southwestern U.S.A. Cosmogenic radiocarbon flux over 8,000 years, as measured in tree rings, discloses comparable variability, the flux-rate being inversely proportional to the magnetic field intensity.

\section{Other Exogenetic Causes}

A climatic linkage between year-by-year ${ }^{14} \mathrm{C}$ measurements and tree-ring width is possible in favoured areas (Sonett and Suess, 1984). The roughly 500- to 2,500-year periodicities also seem to be reflected in many Holocene time series, ranging from ice cores to varves, and tree-rings to cave stalactites. Lake cores obtained from East Africa, the Indus Valley and Kashmir (e.g. Singh and Agrawal, 1976) seem to reflect very large climatic signals that have significant messages for paleomonsoon reconstruction.

Of particular interest is the work of Singh and others (1972) and of Bryson and Swain (1981) on the Indus ValleyRajasthan lakes, which shows the important role of winter

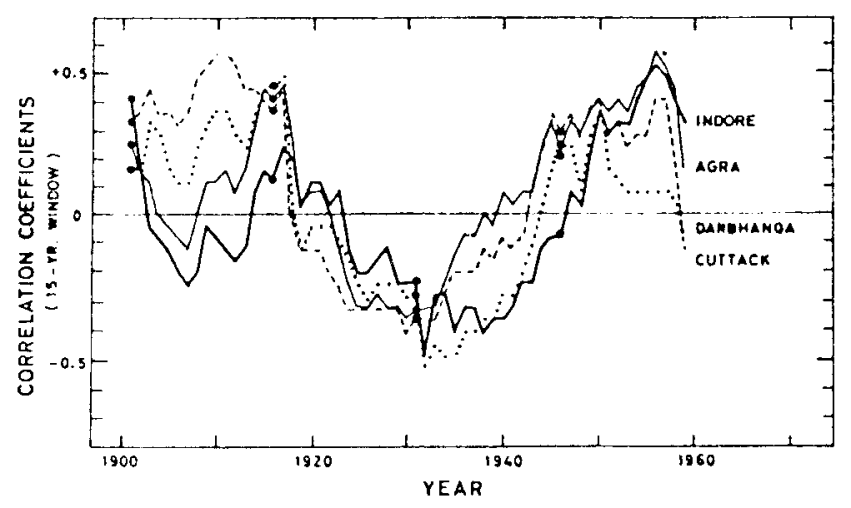

Figure 6: Variations in the correlation coefficients between sea-level pressure in August and the mean annual sunspot number for the Indian Peninsula. Cuttack is in the south $\left(20^{\circ} \mathrm{N}\right)$ and Agra in the North $\left(17^{\circ} \mathrm{N}\right)$, From Bell (1977). 
(prevailing westerly) rains prior to about $3,600 \mathrm{yBP}$. These fluctuations seem, in general, to be in phase with summer, monsoonal rains, a failure of one matching a failure of the other.

Figure 7 shows that the rainfall record here can be divided broadly into three intervals. An early Holocene period is characterized by strong monsoons, very light winter rains, insolation being marked by hot northern summers and very cold winters. A somewhat similar middle Holocene period followed with fluctuating eycles of about 500 years of winter rains as great as the monsoon. In the late Holocene a catastrophic collapse of regular monsoonal rains, with general desertification before $3,000 \mathrm{yBP}$, was followed by a weak to moderate monsoon; due to precession the insolation changes to cool summers and milder winters in Central Asia. 'The collapse of the Harappan culture was clearly related to a climatic change that was astronomically forced.

Bryson and Swain (1981) also demonstrate that a 1,000-year temperature reconstruction from Iceland may even be proxy for rainfall in northwestern India. Famines match the minima. A synchronism of this sort would again tend to suggest exogenetic causes, rather than some sort of endogenetic dynamic fluctuation in the general atmospheric circulation.

\section{Ocean Temperatures}

The role of SS'I's in monsoonal dynamies has been attracting considerable attention recently. Work in China and Japan shows that the strength of the warm Kuro-Shio Current is a clear indicator of the Chinese monsoon (Lau and Li, 1984), the North Pacific oceanic gyre being linked in turn to the California and Peru currents (Yoshino and Xie, 1983).

Expansion of the north Pacific anticyclone was a feature of the early Holocene (Heuser et al., 1985), and since then it has certainly fluctuated (Fig. 8). During the "Little Climatic Optimum" ( $\mathrm{AD} 800-900$ ), the time of the Viking ascendancy in northern Europe and the colonization of Iceland and Greenland, the Pacific Polar Frontal Zone (PFZ) followed a line through Beijing, central Korea and

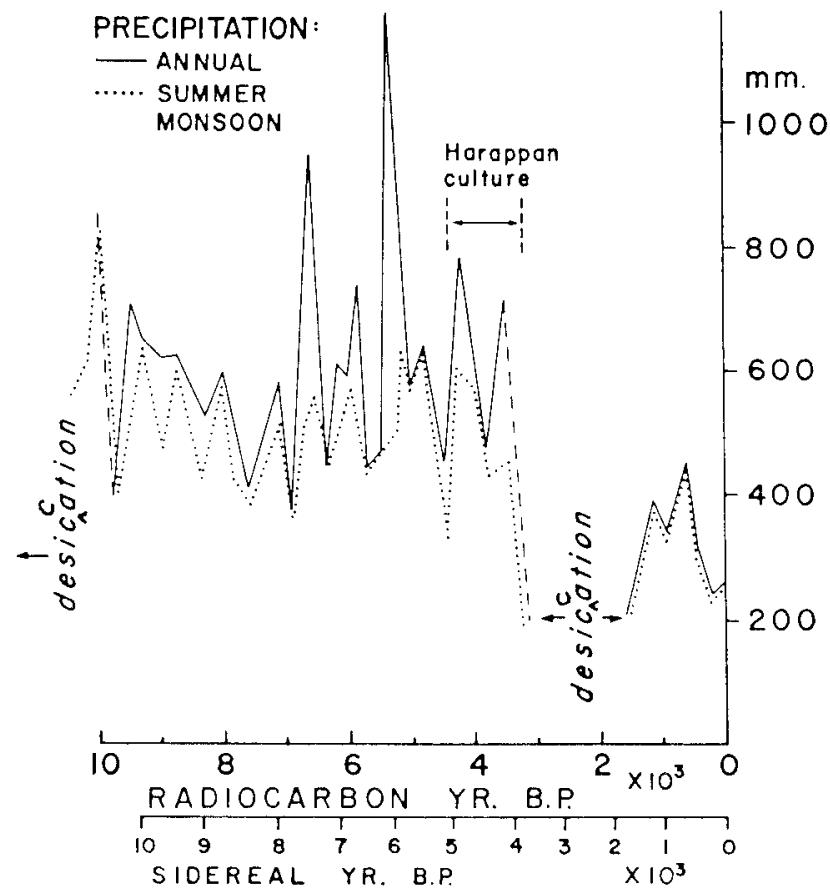

Figure 7: A Holocene raintall record for Rajasthan, India, based on lacustrine pollen (Singh et al., 1972) and climatic reconstruction by Bryson and Swain (1981).
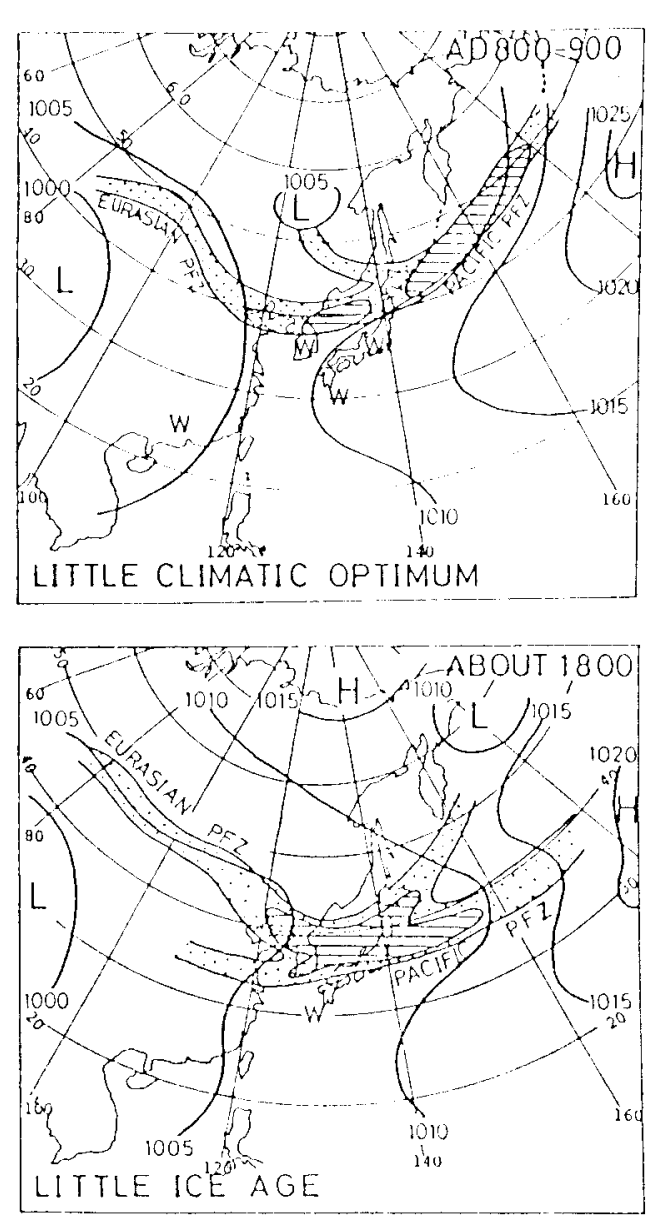

Figure 8: The use of cimatic proxies in reconstructing synoptic patterns. A summer regime over East Asia is illustrated. From Yoshino (1978).

Hokkaido. By AD 1800, during the "Little Ice Age," when the mean annual temperature fell on average about $2^{\circ}-3^{\circ}$ relative to the $A D 800$ value, the $\mathrm{PFZ}$ had shifted to a belt passing close to Shanghai and the southern coast of Japan, an average latitudinal shift of about $500 \mathrm{~km}$. The warm waters of the Kuro-Shio formerly helped bring monsoonal summer rains to much of Japan and China.

Holocene cores off Santa Barbara disclose astonishing temperature variations in the California Current (Pisias, 1978). Modelling studies at the U.t. Meteorological Uffice are now attempting to predict detailed monsoon behaviour from SSTs to an 8-day precision (Kershaw, 1985). Unfortunately, at SSTs above $28^{\circ} \mathrm{C}$, the temperature does not correlate well with the convective cloudiness of the ITCZ (Gadgil et al., 1984).

In the northern parts of the Indian Ocean, the ancient SSI's and upwelling areas have been reconstructed as far back as the Late Pleistocene by the use of planktonic proxies, $18 \mathrm{O} / 16 \mathrm{O}$ isotopic analyses (Prell, 1984) and microfossil evidence of salinity (Duplessy, 1982; Cullen, 1982). Figure 9 shows the present-day situation for the Indian Ocean Southwest Vlonsoon in August. Leep-sea cores (V34-88 and others) have shown the on-off nature of upwelling near southern Arabia, depending on the strength of the monsoun. The latter reached a maximum about 9,000 yBP (Prell, 1984). About $18,000 \mathrm{yBP}$, at the height of the last glaciation, the insolation was similar to that of today, but 


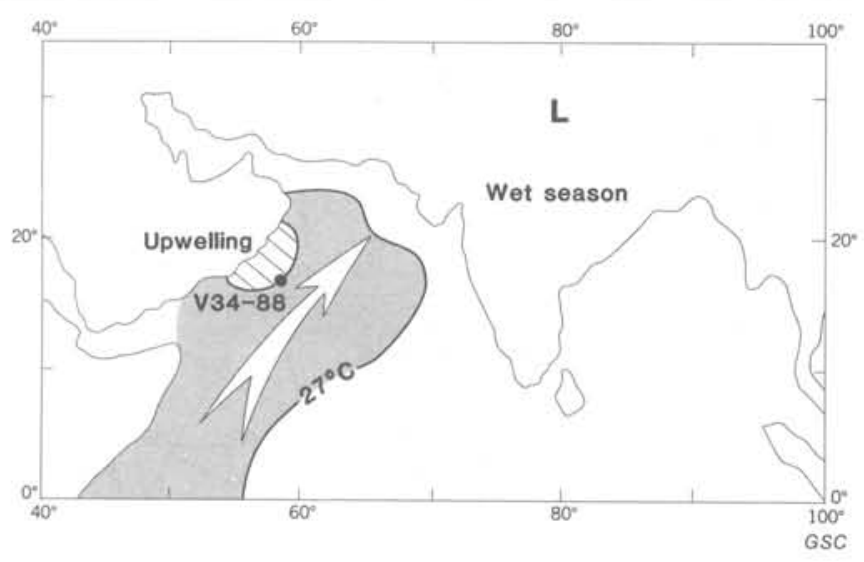

Figure 9: The role of the warm Somali Current (SST up to $27^{\circ} \mathrm{C}$ ) during the present-day monsoon in the northern Indian Ocean. $L$ - the low pressure zone of high insolation and low albedo over the northern Himalayas and Tibet. After Prell (1984).

the Central Asian albedo was much higher; foraminiferal evidence suggests that upwelling was very much reduced and may at times have ceased altogether.

There seems little doubt that in a glacial stage the trade winds were generally enhanced and so were the great oceanic gyres. The lower SSTs, together with higher continental albedos caused by cooler summers (lower central Asiatic land-surface temperatures) combined to weaken the monsoonal circulation. The growth of ice eaps and snowlines at least $1,000 \mathrm{~m}$ lower in the Himalayas and other mountains of Central Asia must have created a high albedo and semi-permanent high pressure system, at times almost totally inhibiting the Asiatic Monsoon and favouring cold, dry, radially directed air flow.

\section{Modelling Studies}

Today, in Central Asia, satellite monitoring shows that increased snow cover effectively reduces or delays monsoonal rains (Dey and Bhanu Kumar, 1982). The dynamics seem to be supported by modelling studies (Manabe and Hahn, 1977; Kutzbach, 1981), but the role of the snowcover albedo should not be overstated because it will not work for the East Africa and North Australia monsoons that failed just as totally as did the Indian monsoon (Rognon and Williams, 1977; Nicholson and Flohn, 1980). In these areas, the fall in precipitation led to widespread desertification, which also raised the albedo. Sedimentological and paleontological analyses of the Nile discharge (Fairbridge, 1962, 1976), East African lakes and eastern Mediterranean (Rossignol-Strick, 1983) demonstrate that the East African rains were so depleted at the glacial maxima that Lake Victoria did not overflow and the Nile became a seasonal stream, at one stage reduced to a trickle.

Paleontological studies in Sri Lanka by Deraniyagala (1941, and personal communication) shows that when sea level was low and glacial-stage animals could migrate there from India the species included those adapted to semi-arid climates, such as the camel and those that live today in northern India. The whole of the Indian Peninsula, much of China, SE Asia and northern Australia were similarly affected by this semi-arid, non-monsoonal regime. The same is true for Africa, South America and the Caribbean (Fairbridge, 1967, p. 539). The warm-up of the Indian Ocean and the return of the monsoonal rains was dramatic and almost synchronous in the surrounding regions, beginning about 13,500 yBP (Street and Grove, 1979; Prell, 1984). The "Pluvial Maximum," about 10,000-7,000 yBP, was most dramatic in the northern and western Sahara where monsoonal fresh-water lakes were formed (Petit-Maire, 1986).

\section{Conclusions}

As a generalization, one may say about the global circulation of today, that strongly zonal winds in the temperate latitudes tend to coincide with strong monsoons. Conversely, blocking systems mean weak monsoons. In glacial periods the vast increase of albedo led to comprehensive blocking and monsoon inhibition. All this clearly needs closer study. Evidently, the monsoon is primarily dependent upon temperature and pressure differentials that seem to have delicate threshold levels. The latter are locked-in to the global climate engine that is, in turn, subject to complex exogenetic forcing. Planetary, solar and lunar periodicities are clearly predictable, but intensive study is needed to clarify the linkage mechanisms.

Because instrumentally based meteorological records are totally incapable of providing data required for precise long-term cycle analysis, great efforts are needed on the part of historians, palynologists, stratigraphers and others, to develop well-dated proxy records of the ancient monsoons, such as evidence of droughts, floods, vegetation changes, and lake-level fluctuations. A basic rethinking of some statistical procedures is also needed (Currie and Fairbridge, 1985). Most importantly we must try to go from the known to the unknown: from observed stratigraphic, geophysical and astronomical events to the inferred atmospheric responses.

Rhodes W. Fairbridge is Emeritus Professor of Geology at Columbia University (Schermerhorn Hall, New York, NY 10027, U.S.A.). Before joining Columbia he taught at the University of Western Australia and nlinois. $\mathrm{He}$ has worked in Iraq, the Sudan, New Guinea, the central Sahara, Bangladesh and many other countries. Prof. Fairbridge has edited numerous encyclopedias in earth sciences and the 90 volume "Benchmark Series in Geology."

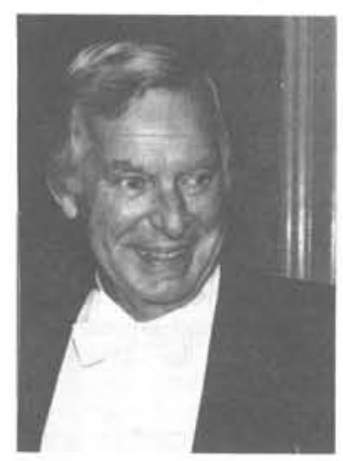

\section{References}

Banerjee, S.K., Lund, S.P. and Levi, S., 1979. Geomagnetic record in Minnesota lake sediments - Absence of the Gothenburg and Erieau excursions. Geology, v. 7, no. 12, p. 588-591.

Bell, G.J., 1977. Changes in sign of the relationship between sunspots and pressure, rainfall and the monsoons. Weather, v. 32, p. 26-32.

Bell, P.R., 1981. The combined solar and tidal influence in climate. In: Sofia, S. (ed.), Variations in the Solar Constant. NASA Publication, Washington, p. 241-254.

Borisenkov, Y.P., Tsvetkov, A.V and Agaponov, S.V., 1983. On some characteristies of insolation changes in the past and in the future. Climatic Change, v. 5, p. 237-244.

Bryson, R.A. and Swain, A.M., 1981. Holocene variations of monsoon rainfall in Rajasthan. Quaternary Research, v, 6, no. 2, p. $135-145$.

Bucha, V., 1984. Mechanism for linking solar activity to weatherscale effects, elimatic changes and glaciations in the northern hemisphere. In: Mörner, N.A. and Karlén, W. (eds.), Climatic changes on a yearly to millennial basis, D. Reidel, Dordrecht, p. 415-448.

Creer, K.M., 1981. Long-period geomagnetic secular variations since 12,000 yr BP. Nature, v. 292, no. 5820, p. 208-212.

Cullen, J.L.. 1982. Microfossil evidence for changing salinity patterns in the Bay of Bengal over the last 20,000 years. Palaeogeography, Palaeoclimatology, Palaeoecology, v. 35 , no. $2-4$, p. 315-356. 
Currie, R.G., 1984. On bistable phasing of 18.6-year nodal induced flood in India. Geophysical Research Letters, v. 11, no. 1, p. 50-53.

Currie, R.G. and Fairbridge, K.W., 1985. Periodic 18.6-year and cyclic 11-year induced drought and flood in northeastern China, and some global implications. Quaternary Science Reviews, v. 4, no. 2, p. 109-134.

Das, P.K., 1968. The Monsoons. New Lelhi National Book Trust.

Das, P.K., 1984. The monsoons - a perspective. Indian National Science Academy, New Delhi. Perspective Report Series, no. 4, 52p.

Deraniyagala, P.k.P., 1941. The hippopotamus as an index to early man in India and Ceylon. Science and Culture, Calcutta, v. 7, no. 2 , p. $66-68$.

Dey, B. and Bhanu Kamar, O.S.R.U., 1982. An apparent relationship between Eurasian spring snow cover and the advance of the Indian summer monsoon. American Meteorological Society Bulletin, v. 2l, p. 1929-1932.

Duplessy, J.C., 1982. Glacial to interglacial contrasts in the northern Indian Ocean. Nature, v. 295, no. 5849, p. 494-498.

Fairbridge, R.W., 1962. New radiocarbon dates of Nile sediments. Nature, v. 196, no. 4850, p. 108-110.

Fairbridge, R.W., (ed.), 1967. Eneyclopedia of Atmospheric Sciences and Astrogeology. Reinhold, New York, 1200p.

Fairbridge, k.W., 1976. Effects of Holocene climatic change on some tropical geomorphic processes. Quaternary Research, v. 6, no. 4, p. 529-556.

Fairbridge, R.W., 1982. The Pleistocene-Holocene boundary. Quaternary Seience Reviews, v. 1, no. 3, p. 215-244.

Fairbridge, R.W., 1984. The Nile floods as a global climatic/solar proxy. In: Mörner, N.A. and Karlén, W., (eds.), Climatic changes on a yearly to millennial basis. D. Reidel, Dordrecht, p. 181-190.

Fairbridge, R.W. and Hillaire-Marcel, C., 1977. An 8,000-yr palaeoclimatic record of the 'Double-Hale' $45-\mathrm{yr}$ solar eycle. Nature, v. 268, no. 5619, p. 413-416.

Filion, L., 1983. A relationship between dunes, fire and climate recorded in the Holocene deposits of Quebec. Nature, 1984, v. 309, no. 5968 , p. 543-546.

Gadgil, S., Joseph, P.V. and Joshi, N.V., 1984. Oceanatmosphere coupling over monsoon regions. Nature, v. 312 , no. 5990, p. 141-143.

Halley, E., 1686. An historical account of the trade-winds and monsoons observable in the seas near the tropies with an attempt to assign the physical causes of such winds. Philosophical Transactions, Royal Society of London, v. 26, p. 153-168.

Hastenrath, S., 1985. Climate and circulation of the tropies. D. Reidel, Dordrecht, $455 \mathrm{p}$.

Hastenrath, S. and Lamb, P.J., 1980. On the heat budget of hydrosphere and atmosphere in the Indian Ocean. Journal Physical Oceanography, v. 10, p. 694-708.

Heusser, C.J., Heusser, L.E. and Peteet, D.M., 1985. LateQuaternary climatic change on the American North Pacific coast. Nature, v. 315 , no. 6019 , p. 485-487.

Hillaire-Marcel, C., 1976. La déglaciation et le relèvement isostatique sur la côte est de la Baie d'Hudson. Cahiers de Géographie de Québec, v. 20, no. 50, p. 185-220.

Jose, P.D., 1965. Sun's motion and sunspots. Astronomical Journal, v. 70, p. 193-200.

Kershaw, K., 1985. Onset of the south-west monsoon and seasurface temperature anomalies in the Arabian Sea. Nature, v. 315, no. 6020 , p. $561-563$.

Kutzbach, J., 1981. Monsoon climate of the early Holocene: climate experiments with the Earth's orbital parameters for 9,000 years ago. Science, v. 214 , no. 4516, p. 59-61.

Landscheidt, T., 1984. Cycles of solar flares and weather. In: Mörner, N.A. and Karlén, W. (eds.), Climatic changes on a yearly to millennial basis. D. Reidel, Dordrecht, p. 473-481.

Lau, Ka-Ming and Li, Mai-Tsun, 1984. The monsoon of East Asia and its global associations: a survey. American Meteorological Society Bulletin, v. 65, p. 114-125.

Lawrence, E.N., 1965. Terrestrial climate and the solar cycle. Weather, v. 20 , p. 334-343.
Legrand, J.P. and Simon, P.A., 1985. Some solar eycle phenomenia related to the geomagnetic activity from 1868 to 1980 . The shock events. Astronomy and Astrophysics, v. 152, p. 199-204.

Loomis, E., 1868. A treatise on meteorology. Harper, New York.

Manabe, S. and Hahn, D.G., 1977. Simulation of the tropical climate of an ice age. Journal Geophysical Kesearch, v. 82, no. 27, p. $3889-3911$.

Viooley, D.A. and Parthasarathy, B., 1984. Fluctuations in all-India summer monsoon rainfall during 1871-1978. Climatic Change, v. p. 286-301.

Nicholson, S.E. and Flohn, H., 1980. African environmental and climatic changes and the general atmospheric circulation in Late Pleistocene and Holocene. Climatic Change, v. 2, no. 4, p. 313-343.

Pédelaborde, P., 1963. The Nonsoon. Ni.J. Clegg, translator. Methuen, London, 196p.

Petit-Waire, N., 1986. Palaeoclimates in the Sahara of Mali: a multi disciplinary study. Episodes, v. 9, no. 1, p. 7-16.

Philander, S.G.H., 1983. El Niño southern oscillation phenomena. Nature, v. 302 , no. 5906, p. 295-301.

Pisias, N.G., 1978. Paleoceanography of the Santa Barbara Basin during the last 8000 years. Quaternary Research, v. 10, no. 3 , p. 366-384.

Pittock, A.B., 1983. Solar variability, weather and climate: in update. Quarterly Journal of the Royal Meteorological Society, v. 109, p. $23-55$.

Prell, W.L., 1984. Monsoonal climate of the Arabian Sea during the late Quaternary: a response to changing solar radiation. In: Berger, A., et al. (eds.), Milankovitch and Climate. D. Reidel, Dordrecht, p. $349-366$.

Ramage, C.S., 1971. Monsoon meteorology. Academic Press, New York and London, 296p.

Rampino, Ni.R. and Stothers, R.B., 1984. Geological rhythms and cometary impacts. Science, v. 226, no. 4681 , p. $1427-1432$.

Rasmusson, E.M. and Wallace, J.M., 1983. Meteorological aspects of the $\mathrm{El} \mathrm{Niño/Southern} \mathrm{Oscillation.} \mathrm{Science,} \mathrm{v.} \mathrm{222,} \mathrm{no.} \mathrm{46 \% 4,}$ p. $1195-1202$.

Riehl, H., 1979. Climate and weather in the tropics. Acadenic Press, London, $611 \mathrm{p}$.

Rognon, P. and Williams, M.A.J., 1977. Late Quaternary elimatic changes in Australia and North Africa: a preliminary interpretation. Palaeogeography, Palaeoclimatology, Palaeoecology, v. 21 , no. 4, p. $285-327$.

Rossignol-Strick, Wh., 1983. African monsoons, and immediate climate response to orbital insolation. Nature, v. 304, no. 5921, p. 40-49.

Schove, D.J., 1983. Sunspot eycles. Hutchinson Ross. (Benchmark Papers in Geology, vol. 68), Stroudsburg, 395p.

Singh, G. and Agrawal, D.P., 1976. Radiocarbon evidence tor deglaciation in north-western Himalaya, India. Nature, v. 2tit, no. 5548 , p. $232-233$.

Singh, G., Joshi, R.D. and Singh, A.B., 1972. Stratigraphic and radiocarbon evidence for the age and development of three salt lake deposits in Rajasthan, India. Quaternary Research, v. 2, no. 4, p. 496-505.

Sonett, C.P. and Suess, H.E., 1984. Correlation of bristlecone pine ring widths with atmospheric $14 \mathrm{C}$ variations: a climate-Sun relation. Nature, v. 307, no. 5947, p. 141-143.

Street, F.A. and Grove, A.T., 1979. Global maps of lake-level fluctuations since 30,000 yrBP. Quaternary Research, v. I2, p. $83-118$.

Thouveny, N., Creer, K.M., Smith, G. and Tucholka, P., 1985. Geomagnetic oseillations and excursions and Upper Pleistocene chronology. Episodes, v. 8, p. 180-182.

Yoshino, M.M., 1978. Regionality of climatic change in monscon Asia. In: Takahashi, K. and Yoshino, Ni.W. (eds.), Climatic change and food production. University of Tokyo Press, p. 331-342.

Yoshino, v.M. and Xie, S., 1983. A preliminary study of climatic anomalies in East Asia and sea surface temperatures in the North Pacific. Science Reports of the Institute of Geoscience, University of Tsukuba, Section A, v. 4, p. 1-23. 